UDC 811.161.2'373.46:791

DOI https://doi.org/10.32841/2409-1154.2021.47-1.40

\author{
Loskutova N. M., \\ Candidate of Philological Sciences, \\ Associate Professor at the German and French Philology Department \\ Mariupol State University
}

\title{
POLYSEMY IN CINEMATOGRAPHIC TERM SYSTEM OF THE UKRAINIAN LANGUAGE
}

\begin{abstract}
Summary. The article considers peculiarities of the lexicosemantic process of polysemy in the cinematographic term system of the Ukrainian language (CTSUL). The presence of polysemy in the field of terminology can be explained by the public need for permanent change and improvement of human knowledge. In spite of the rigidity of requirements imposed on terms as regards to preciseness of their meanings, the present research shows that such a phenomenon in the CTSUL as polysemy is available but not appreciably widespread: $2.8 \%$ of the Ukrainian cinematographic terms (CTs) are polysemic. It was found that both monolexemic and polylexemic CTs can be polysemic, but the vast majority in the CTSUL is constituted exactly by monolexemic terms. The number of meanings in polysemic CTs can vary from two to six. Most of the Ukrainian polysemants primarily have two meanings, whereas three or more meanings within the CTSUL are rather an exception to the rule.

It was discovered that polysemy in the CTSUL is developing in conformity with the types of transfers of the lexical meaning: metonymic and metaphoric transfers as well as expansion and contraction of the lexical meaning. The most frequent method of creating new meanings appeared to be metonymic transfer, where there is a real connection between the subjects and the phenomena named by CTs. Of all the types of metonymic transfers, only the models "the process $\rightarrow$ the presentive meaning" and "part $\rightarrow$ whole" are the most productive ones in the CTSUL.
\end{abstract}

Metaphoric development of polysemy in the CTSUL is less frequent as compared to metonymic transfer. The following types of metaphoric transfers were defined in the CTSUL: in conformity with similarity of functions and the method of action; in conformity with similarity of characteristics and phenomena; in conformity with external similarity. The transfer in conformity with similarity of functions appeared to be mostly widespread.

An insignificant number of terms in the CTSUL were formed by expansion of the meaning which is understood as an increase in the semantic volume of the term. As far as contraction of the CT's meaning, it appeared to be rather an infrequent type of polysemic transfer.

The development processes of polysemy within the CTs are directly determined by phenomena of cinematographic reality. The Ukrainian language failed to avoid the phenomenon of polysemy, which is explained by development of the conceptual system of cinematography caused by technological development.

Key words: term system, term, polysemy, metonymic transfer, metaphoric transfer, expansion of the meaning, contraction of the meaning.

Problem statement. The $20^{\text {th }}$ and the $21^{\text {st }}$ centuries of the $2 \mathrm{~d}$ millennium are distinguished by technological development and rapid development of all the fields of human knowledge. The natural consequence of this process is dramatic increase in the number of specialized terms meant to nominate new notions. The quantitative analysis of most of the term systems has greatly increased. At the same time, scientists were faced by the problem of nominating new notions, since "concreteness of the experience is unlimited; the resources of the richest language are strictly limited" $[18$, p. 65]. Not one of the languages is in condition to respond to every innovation by creating a separate lexeme. This would have brought about uncontrollable enlargement of the vocabulary. As a result, the language would have stopped being an adequate means of communication. Eventually, the terms available in the term systems are exposed to natural influence of the common language process of polysemy, which leads to emergence of dialectical withstand: the monosemic nature the terms is seeking collides with the polysemic nature of the term generated by the principle of economy of language means.

Analysis of recent researches. Numerous linguistic works are concerned with solution to this problem. Among them are articles, monographs, student books and thesis works (see works by renowned Ukrainian and foreign scientists V. Danilenko, B. Golovin, S. Griniew, L. Kapanadze, T. Kyak, V. Leychik, D. Lotte, A. Reformatskiy, L. Simonenko, A. Superanskaya, M. Vakulenko; M.T.Cabré, L. Guilbert, K. Loenning, G. Petit, A. Polguère, H. Sonneveld, F. Steurs, E. Wüster, etc.). Some scientists put forward the assumption that polysemy is an extremely negative phenomenon in terminology and has to be eliminated by all means $[9 ; 12 ; 15]$. This view is based on the fact that monosemy is undoubtedly one of the most important and desired features of the term. The first requirement to be imposed on the term is a precisely limited professional application within which the term must logically and unambiguously correspond to a certain notion and to precisely nominate it, which must result in achievement of the term's monosemy. Despite polysemy is a natural manifestation of the impact produced by the main development principles of the language's vocabulary, its presence within one terminology is extremely undesirable and in standardizing it, it is expedient to seek unambiguous correlation between the term and the notion.

According to other scientists (whose viewpoint is shared by us), presence of polysemy in the field of terminology can be explained by the public need for permanent change and improvement of human knowledge $[4 ; 11 ; 19]$. But since the resources of the language meant to express new notions are limited, this promotes further semantic development of the term available in a particular term system. As a linguistic universal, polysemy makes it possible to economize on means of expression, enlarging the nominative potential of the language [8, p. 94]. In terminology, polysemy of the term 
emphasizes the profundity of a certain idea's or notion's state of knowledge and results from the existence of particular groups of terms connected with one another by causative-consecutive and other relations.

More often than not, polysemy develops on the basis of emergence of a figurative meaning with a primitive term having a direct meaning, this figurative meaning overlapping on the direct meaning and promoting development of polysemy of the term. [2, p. 44]. Polysemy can develop in conformity with the following types of transfers of the lexical meaning: metonymic and metaphoric transfers, expansion and contraction of the lexical meaning.

Thus, the study of polysemy in terminology as well as that of the mechanisms of its formation and manifestation is still a vital problem in modern linguistics. However, in spite of the great amount of works concerned with this problem, not all the term systems underwent detailed analysis. One of those term systems is the term system of cinematography. Today there is research concerned with analysis of structural and semantic peculiarities of cinematographic terms in the Russian language [10], in the English language $[5 ; 16]$ and in the French language [20]. However, there is no linguistic research concerned with the study of polysemy in the cinematographic term system of the Ukrainian language (hereinafter referred to as the CTSUL). The vitality of the research is determined by lacunas in the study of polysemy as one of the systemic phenomena of the Ukrainian language.

The purpose of the article is analysis of the types of polysemic transfers and semantic adjustment of cinematographic terms (hereinafter referred to as CTs) in the Ukrainian language. Achievement of the goal presupposes fulfillment of the following assignments: to define and characterize the main semantic types of polysemants in the CTSUL and to analyze the specificity of polysemic transfers in the given term system.

The object of the research is the CTSUL. The subject of the research is description and analysis of polysemic relations between Ukrainian CTs.

The material of the research was 5388 Ukrainian CTs selected with the help of the method of continuous sampling from lexicographical sources, specialized printed journals, legal acts and cinematographic internet resources.

Presentation of the main material. The lexico-semantic process of polysemy is an integral part of the CTSUL, since polysemic terms are the characteristic of the paradigmatic representation of the term system. In spite of the rigidity of the requirements imposed on terms as regards to preciseness of their meanings, the research shows that there is such a phenomenon in the CTSUL as polysemy. But it is not widespread: $2.8 \%$ of the Ukrainian CTs (138 terms) are polysemic. The necessity of emergence of the additional meaning appears when the notion available in the term system is specified and when there is a need for differentiation of the action and its result or the genre and the work of art belonging to this genre for example. Thus, at the time of the emergence of cinematographic art, the Ukrainian CT кінохроніка meant a series of short films demonstrated in the form of compiled brief information about events of modern life (politics, economics, culture, etc.). These films were previously demonstrated shortly before a feature-length film was. The first newsreels appeared in France in the early $20^{\text {th }}$ century and later spread all around the world. The popularity of those films reached its peak in 1910-1950. At that time another meaning of this CT emerged: that was the way the genre of documentary cinematographic art, the art concerned with description of particular events of modern life began being called [3, p. 1574]. Later, that was the way any documentary filming made directly on the spot or any reportorial filming made in "flashpoint areas" or filming at the time of official events began being called [14, p. 24].

It was revealed that both monolexemic and polylexemic CTs can be polysemic, whereas the bulk is constituted exactly by monolexemic terms $(96.4 \%, 133 \mathrm{CTs})$. This is explained by the fact that with a monolexemic term the semantic structure (based on transfer, comparison or conformation of similar features) is changed easier than with a polylexemic unit as a result of regular reproducibility and frequency of language elements. Besides, terms are characterized by structural and denotative unity and emergence of an additional meaning with one of the components must be semantically agreed with the specifier which is a part of a particular term. Here we will provide an example of the CT поетичне кіно which denotes a film genre uniting films inspired by poetry, being emotionally aureate and chanting clear feelings and the beauty of the nature. These films focus on the characters' personal feelings and there is a big concentration of audio-visual symbols inside them. In 1928 the theoretician B. V. Shklovsky would introduce his understanding of the term поетичне кіно into film studies, namely: a movie where technical issues dominate notional ones, the technical issues replacing notional ones, thus resolving the composition [17, p. 166]. The term поетичний in its second meaning is contrasted to the term прозаїчний, the both terms being consistent in a word combination with a limited number of lexemes. Consequently, one can assume that the characteristic feature of the CTSUL is polysemy of exactly monolexemic CTs.

On the basis of the results of the research, it was revealed that the number of meanings of polysemic CTs can vary from two to six. Statistical analysis determined predominance of the two-meaning terms $(85.6 \%, 118 \mathrm{CTs})$. Thus, the two-meaning term apm-xayc was first used to denote a movie house, where avant-garde movies or film classics were demonstrated for a well-prepared cinemagoer. As time went on, an art house was understood as movies in general for a well-prepared cinemagoer or art films [17, p. 33].

Three-meaning CTs run second in the number of meanings $(9.4 \%, 13 \mathrm{CTs})$. For example, the term мультиплікація was first used to denote a special kind of filming consisting in a series of drawings or solids depicting sequent phases of motion and creating an illusion of stationary objects on the screen. Later that was the way the scene of this kind if filming began being called. Animated cartoons would become a part of cinematography, occupying a firm seat as one of the genres, whereas development of cinematographic technologies promoted animated cartoons being converted into a separate branch of cinematography involved in production of films with the help of that method [3, p. 695].

Four-, five- and six-meaning CTs are rather infrequent in the CTSUL. Their total amount does not exceed 5\% (7 CTs). The CT кіно has the greatest number of meanings. This CT is the apocopation of the term кінематограф. Originally, this term denoted the invention of the Auguste and Louis Lumière Brothers which was first demonstrated to the public on December $28^{\text {th }}$, 1895 at the place "Grand Café" on Boulevard des Capucines in Paris. The CT кінематограф was formed from the Greek kinema - motion and graphein - to write. It is noteworthy that the term синематограф borrowed from French through Russian first appeared in the Ukrainian language in 1896 [7, p. 235]. 
In the early $20^{\text {th }}$ century the clipped variant of the term кинематограф - кино: Kinematographie - Kientopp - Kino кино would come to the Russian language from German. In a while this clipped variant would emerge in the Ukrainian language. Similarly, with words of French origin, in the Russian language and later in the Ukrainian language the stress was transferred to the last syllable [6, p. 448]. These two terms once existed in parallel. However, as a result, the CT кінематограф would squeeze out the term синематограф. This fact is explained by the fact that the sound of the German term was closer to the Old Greek variant kinema which conveyed association with motion [1, p. 7, 10, 19]. As time went on, the CT кінематограф was contracted to the term кіно which began functioning in the Ukrainian language as an independent term with an independent lexical meaning; and later as a contracted term in composite terms. For the first few years since cinematography was invented, the term кіно denoted a camera or a film projector. Since the success of the Lumière Brothers' invention was tremendous, it was spread everywhere: film studios were formed, film exhibitions were organized, materials and means attributed to the film industry were invented and developed. Accordingly, the meaning of the CТ кіно kept being enriched. Soon it was already understood as: 1) contraction of the word кінематограф (denoting a camera or a film projector); 2) a movie house; 3) a movie; 4) cinematography, cinema art; 5) in P. Pasolini's film study, the synonym of the concept "film footage"; 6 ) in J.-L. Cohen's film study, "the phenomenon of cinema" (all the possible social roles of cinematography) [3, p. $541 ; 17$, p. 91$]$. As time went on, cinematography would conquer the whole world and cinema would turn into a full-fledged art, becoming an industry of entertainment and a constituent component of media culture.

On the basis of the aforementioned, one can make a conclusion that Ukrainian polysemants are primarily two-meaning ones, whereas three and more meanings within the CTSUL are rather an exception to the rule.

As a result of the research, it was revealed that polysemy develops in the CTSUL in accordance with the following types of transfer of the lexical meaning: metonymic and metaphoric transfers as well as expansion and contraction of the lexical meaning. Metonymic transfer appeared to be the most frequent way of emergence of new meanings, where there is a real connection between subjects and phenomena named by the term $(81.5 \%, 137$ transfers $)$. Linguists call such a transfer the metonymic type of polysemy [4, p. 32]. In the CTSUL it develops in accordance with the following types of adjacency: action, process $\rightarrow$ presentive meaning; part $\rightarrow$ whole; technique, method $\rightarrow$ object, tool; place $\rightarrow$ object, subject; repository $\rightarrow$ content; material $\rightarrow$ product; subject $\rightarrow$ tool.

Statistics evidences that in the CTSUL the most productive type of metonymic transfer is transfer of the lexical meaning from the action or the process to presentive meanings which interact with procedural ones ( 66 transfers). In the framework of the model "action, process $\rightarrow$ presentive meaning" the following subtypes of metonymic transfers are defined in the CTSUL: action, process $\rightarrow$ result; action $\rightarrow$ technique, method, action $\rightarrow$ subject; action $\rightarrow$ branch, science, action, process $\rightarrow$ index. The subtype of transfer of the meaning from the action to its result is recognized as the most frequent one (43 transfers). Abstract verbal nouns which in denoting process begin denoting presentive meanings appropriate to them are most often "indulge in" polysemy. For example, the СТ склейка originally meant an operation consisting in sticking two film fragments together at the time of montage. Later, by means of transfer of the action to its result, the same CT was used to denote a spot of connecting two film pieces which are glued at the time of montage or while the film is shown should the film be torn apart [3, p. 1332].

Relatively well-spread is metonymic transfer "action $\rightarrow$ technique, method" (12 transfers) which happens when the action or the method of producing thereof becomes the basis of the new cinematographic method or cinematographic technique. Thus, the CT ліпсинк originally meant motion of the character's teeth in animated cartoons. Later it began denoting a form of sound recording where one actor articulates a number of parts, changing his/her voice [13, p. 186].

The other subtypes of transfers from the action to presentive meanings appeared to be unproductive. They are represented by quite a few examples. For example, the subtype "action $\rightarrow$ branch, science" can be illustrated by the example of the CT маркетинг which in the field of media denotes any type of business activity promoting or selling and buying cine, TV and video products. Besides this is the way the theory of media business is called [17, p. 136].

The type of metonymy based on the adjacency "part $\rightarrow$ whole" and vice versa runs second in productivity (48 transfers). In the framework of this model, the example of metonymic transfer "work $\rightarrow$ genre" seems to be interesting, since there are genus-species relations between these notions and one notion is a constituent part of the other. Thus, the process of genre formation in cinematography more often goes on from emergence of original works to creation of a series of derived products which, in terms of a number of generalized characteristics, form a separate film genre, such as кінооповідання: 1) a documentary film built on the form of a story; 2) a cinema genre uniting films of the kind [3, p. 541]; кінофантастика: 1) an aggregate of films of science fiction content; 2) a cinema genre uniting films of the kind [3, p. 542].

Transfer from the technique or method used in film art to the object or tool of impact or its abilities as well as to the result of this technique (16 transfers) runs third. The CТ ексиентрика originally meant the stylistic device of sharpening the film action by means of giving it an understandable character in the form of exaggerations of various kinds, grotesque randomness and awkwardness. Later in cinematography this name was transferred to highly expressive comics or some particular spectacle elements [17, p. 68]

Other types of metonymic transfer are represented in the CTSUL by quite a few examples (16 transfers in total). For example, the type of metonymic transfer "material $\rightarrow$ product" can be illustrated by the CT плівка which originally meant "a transparent elastic band made of special material and covered with a light-sensitive layer; used for photographic and cinematographic snapshots". Later this was the way films in general were called [3, p. 983].

Thus, of all the models of metonymic transfer, only the models "process $\rightarrow$ presentive meaning" and "part $\rightarrow$ whole" are the most productive in the CTSUL. It is connected with the fact that the process as the motivating category and the result as the motivated category are the most important in professional activity, whereas the relation "part $\rightarrow$ whole" are dictated by the development principles of the system from particulars to generals.

Metaphoric development of polysemy in the CTSUL is less frequent compared with metonymic transfer $(11.3 \%, 19$ transfers). The following types of metaphoric transfers were determined in the CTSUL: in accordance with similarity of functions or 
manner of action; in accordance with similarity of characteristics and phenomena; in accordance with external similarity.

Mostly widespread is the transfer in accordance with similarity of functions or manner of action (12 transfers). Commonality or similarity of functions and actions performed by a subject or an object is based on semic interactions: the denotation contains a significant functional feature available in the semic structure of producing lexeme. Thus, the CT кіноплакаm denotes a poster or a film bill issued for the purpose of promoting and disseminating films and film festivals. Film bills are printed in publishing houses and are general circulation items of visual art that can be kept in libraries. No film release can do without creating a bright and colorful film bill, since it is an important promotion element in the process of commercial film production [17, p. 170]. Another meaning of the CT кіноплакат is "a short film or a series of shots of commercial, campaigning and other content" emerged on the basis of similarity of functions performed by films and posters: to convey information, to have an influence, to promote a film/an idea. The popularity of the functional transfer is explained by the fact that when compared, the semantic development of the CT is based on commonality of functions, not taking into consideration external characteristics of the object. In fact, though the CT denotes various notions, it still retains the semantic connection between the meanings.

Metaphoric transfer in accordance with similarity of characteristics or phenomena runs second in productivity (6 transfers). For example, in the early $20^{\text {th }}$ century the CT камеo borrowed by Ukrainian from English (the English language itself borrowed it from the Italian cameo or cammeo which means "cameo") meant any small part of a work of art that distinguished itself among other secondary parts. As time went on, the term would acquire the figurative meaning "an episodic part acted by any famous actor or another celebrity" [14, p. 24] on the basis of similarity of the characteristic "small, insignificant". The term was first used by Producer M. Todd in the film "Around the world for 80 days" starred by many prominent actors. Usually this technique is aimed at boosting the commercial potential of a film.

As far as metaphoric transfer in accordance with external similarity, this type appeared to be unproductive in the CTSUL (1 transfer).

$4.8 \%$ (8 transfers) in the CTSUL were formed by means of expansion of the meaning which involves an increase in the semantic volume of a term. Terms acquire new meanings by means of expanding the functions of initial phenomena: the second meaning normally conveys additional features imposed upon the initial semantics. Thus, the CТ кінофестиваль was first used to denote demonstration of films concerned with a particular theme. Later this term began being used to denote creative competitions between works of art (feature films, chronicles, documentaries, popular-scientific, educational, animated, TV) held in one or in a number of countries [3, p. 983; 14, p. 261]. Or the CT типаж for example: originally that was the way actor who was fit for a certain part due to his physical characteristics. As time went on, the meaning of the term expanded, and it began denoting imagery, a type in visual and theater arts [3, p. 1450].

Contraction of the CT's meaning in the process of which the semic structure of the term reflects only a part of things and phenomena fixed by the initial meaning appeared to be an infrequent type of polysemic transfer (2.4\%, 4 transfers). First the term мова кіно in the wide sense of the word was understood as a system of aesthetic and artistic devices with the help of which film authors convey the content of a film. Nowadays in terms of national culture, this is the way the national language spoken by the characters and with the help of which the entire verbal content of a particular film is conveyed [17, p. 142].

Conclusions. The development processes of polysemy within the cinematographic term system are inseparably connected with phenomena in the cinematographic reality. In spite of the requirement of unambiguity imposed on terms, not all cinematographic terms comply with it. The Ukrainian language failed to avoid the phenomenon of polysemy, which is explained by development of the conceptual system of cinematography predetermined by technological development. Thenumber of meanings in polysemantic terms rarely exceeds 2 meanings. Polysemy is primarily typical of monolexemic terms. The mostly widespread method of creating a polysemant in the cinematographic term system of the Ukrainian language is metonymy in the framework of which meanings are transferred from the action or the process to the presentive meaning as well as from a part to the whole. Metaphoric transfer runs second in frequency. Other types of transfers, such as expansion or contraction of the lexical meaning appeared to be infrequent in the term system under research.

The analysis of cinematographic polysemantic terms presented in the article provides opportunities for comparative research in the field of paradigmatic relations in other languages. Comparative research of the peculiarities of cinematographic polysemantic terms in the Ukrainian and French languages deserves further consideration.

\section{References:}

1. Алаторцева С. Новая кинематографическая лексика в современном русском литературном языке : дисс. ... канд. филол. наук : спец. 10.02.01. Ленинград, 1984. 281 с.

2. Будагов Р. Введение в науку о языке : учебное пособие. Москва : Добросвет, 2003. 544 с.

3. Великий тлумачний словник сучасної української мови 3 дод. і доп. / уклад. і голов. ред. В. Бусел. Київ ; Ірпінь : ВТФ «Перун», 2005. 1728 с.

4. Даниленко В., Волкова И., Морозова Л., Новикова Н. Лингвистический аспект стандартизации терминологии. Москва : Наука, 1993. 127 c.

5. Демчук Т. Структурно-семантичний аналіз термінів кіномистецтва в англійській мові. Типологія мовних значень у діахронічному та зіставному аспектах. 2017. Вип. 33-34. С. 17-24.

6. Етимологічний словник української мови : у 7 т. / уклад.: Р. Болдирев, В. Коломієць, А. Критенко та ін. Київ : Наукова думка, 1985. Т. 2 : Д-Копці. 572 с

7. Етимологічний словник української мови : у 7 т. / уклад.: Р. Болдирев, В. Коломієць, Т. Лукінова та ін. Київ : Наукова думка, 2006. T. 5 : P-T. 704 c.

8. Зеленцова М. Особенности формирования понятийно-терминологического аппарата микросистемы «менеджмент» (на материале украинского и русского языков). Культура народов Причерноморья. 2004. № 54. С. 21-25.

9. Кияк Т. Лингвистические аспекты терминоведения. Киев : УМК BO, 1989. $104 \mathrm{c}$.

10. Лебедева О. Русская кинематографическая лексика (структурно-семантический анализ) : дисс. ... канд. филол. наук : спец. 10.02.01. Днепропетровск, 1984. 205 с.

11. Лейчик В. Терминоведение: предмет, методы, структура. 3-е изд. Москва : изд-во ЛКИ, 2007. 256 с.

12. Лотте Д. Упорядочение технической терминологии. Социальная реконструкичия и наука. 1932. Вып. 3. С. 139-154. 
13. Лукьянова Т. Теоретичні аспекти кіноперекладу з англійської на українську мову. Вісник ХНУ. 2011. № 973. С. 183-187.

14. Миславський В. Кінословник. Терміни, визначення, жаргонізми. Харків : Фоліо, 2007. 328 c.

15. Реформатский А. Мысли о терминологии. Современные проблемы русской терминологии : сборник статей. Москва : Наука, 1986. C. $163-198$

16. Романова Т. Структурные и семантические особенности англоязычной терминологической и профессиональной лексики в анимационном кинематографе : автореф. дисс. ... канд. филол. наук : спец. 45.06.01. Москва, 2020. 18 с.

17. Рутковський О. Український словник-довідник екранних медіа. Київ : ІМФЕ ім. Рильського НАН України, 2007. 306 с.

18. Сепир Э. Избранные труды по языкознанию и культурологии / пер. с англ. ; ред. и предисл. А. Кибрика. Москва : Прогресс ; Универс, 1993. $656 \mathrm{c}$.

19. Туровська Л. Військові звання та посади в Україні : монографія. Киів : Ірпінь ; Перун, 2005. 160 с.

20. Agafonova Serrano S. Traduction alternative dans le cinéma: analyse comparative de la traduction des films français et américains en russe. Littératures. Grenoble : Université Stendhal Grenoble 3, 2012. 96 p.

Лоскутова Н. М. Полісемія в кінематографічній терміносистемі української мови

Анотація. У статті розглянуто особливості лексико-семантичного процесу полісемії в кінематографічній терміносистемі української мови (КТУМ). Наявність полісемії у сфері термінології можна пояснити суспільною потребою в постійній зміні та вдосконаленні людських знань. Попри суворість вимог, що висуваються до термінів щодо точності їхніх значень, проведені дослідження показують, що в КТУМ таке явище, як полісемія, $\epsilon$, але не дуже поширене: багатозначними $є 2,8 \%$ українськомовних кінематографічних термінів (КТ). Виявлено, що багатозначними можуть бути як монолексемні, так і полілексемні КТ, але більшість у КТУМ становлять саме монолексемні терміни. Встановлено, що кількість значень у багатозначних КТ може варіюватися від двох до шести. Українськомовні полісеманти переважно є двозначними, а наявність трьох і більше значень у межах КТУМ є скоріше винятком.

3'ясовано, що у КТУМ полісемія розвивається за такими типами перенесення лексичного значення, як метонімічне та метафоричне перенесення, розширення та звуження лексичного значення. Найбільш частотним шляхом творення нових значень виявилося метонімічне перенесення, за якого існує реальний зв'язок між названими термінами, предметами або явищами. 3 усіх типів метонімічного перенесення лише моделі «процес $\rightarrow$ предметне значення» та «частина $\rightarrow$ ціле» $є$ найбільш продуктивними в КТУМ.

Метафоричний розвиток полісемії в КТУМ є менш частотним порівняно з метонімічним перенесенням. У КТУМ виокремлено такі типи метафоричних перенесень: за подібністю функцій або способу дії; за схожістю характеристик, явищ; за зовнішньою подібністю. Найбільшого поширення отримало перенесення за подібністю функцій.

Невелику кількість у КТУМ було утворено шляхом розширення значення, яке передбачає збільшення семантичного обсягу терміна. Щодо звуження значення КТ, то воно виявилось нечастотним типом полісемічного перенесення.

Процеси розвитку багатозначності в межах КТ безпосередньо обумовлені явищами кінематографічної дійсності. Українській мові не вдалося уникнути явища полісемії, що пояснюється розвитком поняттєвої системи кінематографії, обумовленим технічним прогресом, що спричиняє зміни у семантичній структурі терміна.

Ключові слова: терміносистема, термін, полісемія, метонімічне перенесення, метафоричне перенесення, розширення значення, звуження значення. 